\title{
Annual patterns of family and children's diet in three Guatemalan Indian communities*
}

\author{
By MARINA FLORES, BERTA GARCfA, ZOILA FLORES \\ AND MARTA YOLANDA LARA \\ Institute of Nutrition of Central America and Panama (INCAP), \\ Guatemala, $C A$
}

(Received 20 Fune 1963-Accepted 25 February 1964)

Three Mayan Indian towns in the highlands of Guatemala were selected for a field research project by the Institute of Nutrition of Central America and Panama (INCAP). As part of the exploratory phase of the project a dietary survey was made in each of the three towns, and was repeated every year for 4 years in order to compile detailed information on the food consumption of preschool children. The collection of such information, on an individual basis, presents many problems, particularly when dealing with children in this age group, and it was often necessary to study the total family consumption simultaneously. The survey included, therefore, both preschool children and their families, and was designed, not only to estimate the nutrient intake on one particular occasion, but to learn also if such intakes varied from time to time or remained at about the same level.

'The opportunity seldom occurs of studying the food habits of communities over 4 years and at the same time to observe the people's reaction to different methods of inquiry. Flores and her colleagues conducted surveys on previous occasions in two of the towns (Flores \& Reh, 1955; Flores, Flores \& Meneses, 1957). Representative population samples were taken in which the family consumption was recorded over a period of 7 days. The results of these earlier surveys were similar to the figures obtained during the study now recorded.

\section{EXPERIMENTAL}

The communities studied. One of the main characteristics of these rural villages is the social and economic homogeneity of the families. Most of these Indian families are very poor. They live in huts, wear typical Indian dress and speak their native languages. The majority of the schoolchildren and the men also speak Spanish, the former in school and the latter with Ladino persons in the markets where they sell their goods.

All the men are farmers and work their own land, maize and beans being the staple crops. Occasionally, when space permits, they grow fruits and vegetables near their homes. Some of the women weave cloth for domestic use as well as commercial items which they carry to the city markets.

\section{* INCAP Publication I-285.}


The climate is relatively cold for the tropics, especially during the latter part of the year when it becomes quite windy. The altitude is from 6000 to $7000 \mathrm{ft}$ above sea level. In these localities the mean annual temperatures are between 17 and $20^{\circ}$. Agricultural methods are rudimentary and the hand implements employed represent the major cash expenditure during the year. Most families live from their own agricultural products. In spite of the similarity among these three towns, certain basic differences may affect food consumption, directly or indirectly. The water supply in two of the communities is abundant and several public fountains have been erected in the towns. In the third town cottages have recently been constructed by city families, and the demands of these families for water have accentuated a general scarcity.

The first community, Santa Catarina Barahona, town A, is one of three towns clustered in a small valley surrounded by mountains. Although the main highway leading to the capital lies some distance away, Antigua, one of Guatemala's main cities, can be easily reached, which facilitates intensive trading.

The second community, Santa María Cauqué, town $B$, is the nearest town to Guatemala City and is located close to the highway. Before the construction of the Pan American Highway in $195^{\circ}$ this community was isolated to a greater degree and was rarely visited by outsiders. During the past few years, however, the town has been visited by many investigators in the course of their work.

For many centuries the third community, Santa Cruz Balanyá, town C, has remained nearly isolated from the cities, for it is approximately $5 \mathrm{~km}$ from the main roads. It communicates principally with neighbouring Indian communities.

The total population of town A was about 900 , of town B about 975, and of town C about 2100 at the time of the survey.

These three towns differ somewhat in language, costume and housing. Climatic differences account for the variation in agricultural products. For example, Santa Cruz produces, besides maize and beans, some wheat and potatoes and, in season, there is an abundance of peaches and plums. In Santa Catarina, maize, beans, green vegetables and oranges are grown in large quantities. In Santa María Cauqué, however, with the exception of the vegetables grown by a few families possessing home vegetable gardens, production is limited to maize and beans.

In Santa Cruz Balanyá the land is flat, which facilitates the pasturing of cows. Although there are very few animals in the town, some families raise goats. Almost every family owns one or more hens. These are poorly tended and egg production is of no significance.

Method. To obtain the dietary information, the mothers of the preschool children were visited once or twice a day for a period of 3 days. Records of the amounts of food used by the family as a whole, and of the portions consumed by the selected child, were obtained. Because most visits were made at meal times, weights of raw and cooked foods could often be recorded; portions served to the child were estimated, spoons, cups and other household measures being used.

Dietary information from the area was already available on the daily variability of nutrient intake. It had been established that a 3 -day sample gives sufficient information to estimate the average food consumption of a preschool child. 'The 3 -day periods 
included different days of the week for different families, in order to cover the whole week. Average family consumption levels obtained in this way were similar to those of the previous investigation of 1950 , in which 7-day periods were used.

Some families were investigated on Tuesday, Wednesday and Thursday, the rest on Friday, Saturday and Sunday in order to take into consideration some market oscillations already known. From the previous 7 -day family surveys, it was known that families usually visit the market twice a week. The surveys were carried out during the first months of the rainy season (April, May and June).

In towns $A$ and $B$ the mothers were able to speak sufficient Spanish for direct questioning, but in town $\mathrm{C}$ it was necessary to use interpreters for about $40 \%$ of the families. It was found that the most reliable interpreters were girls within the families who were attending school.

There was no problem with wasted food in these communities, because of the limited amount of food available in the homes. However, food given to the animals, especially to dogs and pigs, presented difficulties in estimating the amount of maize consumed by the family. Although it was easier to record the total amount of maize used, it was more accurate to count the number of tortillas eaten by each member of the family at each meal. The latter method was applied unless the mothers were unable to remember the number of tortillas per person per meal.

The surveys carried out during the Ist year (1959) in each town presented the difficulties and psychological problems that a nutritionist always expects in this type of work. In the and and subsequent years different reactions were observed in each town according to the type of programme carried out among the families. In town $\mathbf{B}$, where medical treatment was offered as part of the INCAP research project, the acceptance by the families was good. In town $\mathrm{C}$, which received no treatment of any kind, families reacted in a similar, favourable way, especially those already visited in the previous year. In town $A$, where a feeding programme was offered on a free basis to the preschool children, the reaction of some families was negative. They were reluctant to give information to the nutritionist, claiming they did not need to be included in the feeding programme.

Random population samples for investigation were drawn each year from each town. For the Ist and and years each sample included thirty families and thirty children. For the $3^{\text {rd }}$ and $4^{\text {th }}$ years the sample was reduced to twenty families and twenty children; it was considered that this number was sufficient because of the small variability encountered in the previous 2 years. Some families were studied on more than one occasion.

Treatment of the results. The nutrient content of each food recorded in the family or child's diet was calculated from the INCAP Food Composition Table (Instituto de Nutrición de Centro América y Panamá, $1953 b$ ). For certain wild green leaves not yet analysed the values given for plants of a similar nature were used. Except for the tortilla, no corrections for cooking losses were applied; for the tortilla a detailed study of chemical changes during preparation has been made (Bressani, Paz y Paz \& Scrimshaw, 1958), and values for the composition of the cooked tortilla were taken.

The table of recommended dietary allowances designed by the Instituto de 
Nutrición de Centro América y Panamá (1953a) (elaborated on the basis of the FAO recommendations for calories; for nutrients the figures of the (USA) National Research Council were adapted) was used to measure the adequacy of the family and children's diets, the meal attendance of each family member being taken into consideration. Age, sex and weight of the members of each family were taken into account. Table I shows that $58 \%$ of the total population were less than 15 years old, and relatively few were over 50 years.

Table I. Family size, age and sex distribution of the population surveyed, including the three towns in 1959

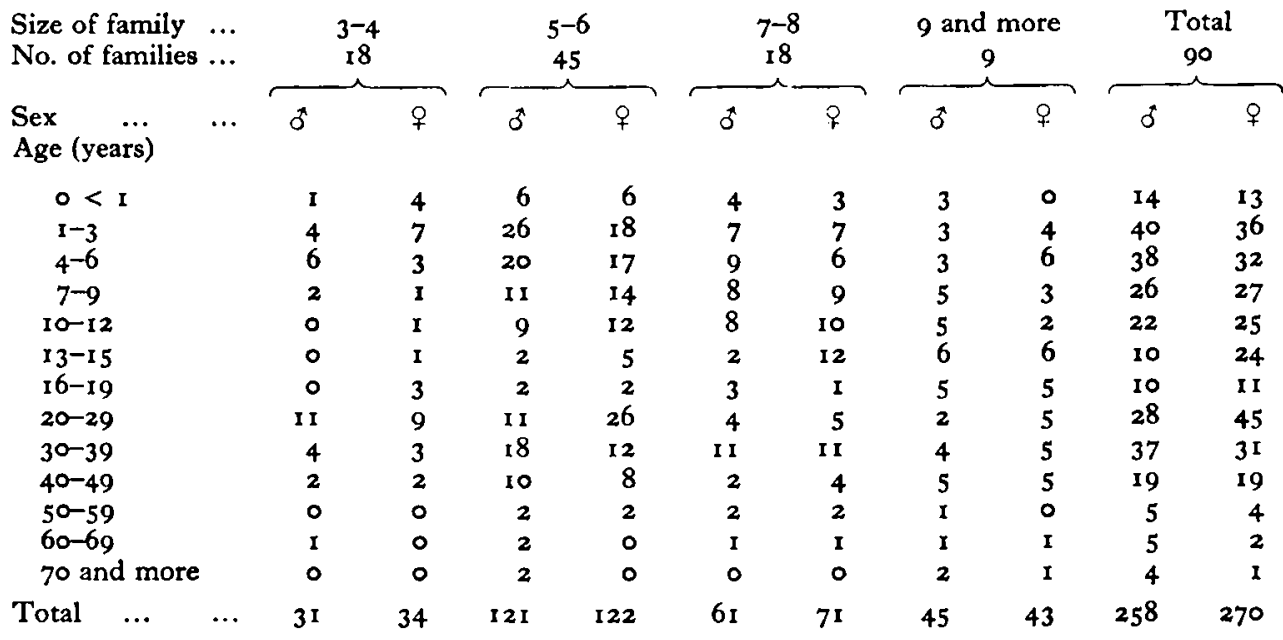

The diets of children and families in town A were calculated in two different ways, with and without the supplementary food given to preschool children. The figures given in Tables 2-4 and 6 refer only to the home consumption without the supplement offered to the young children. In addition, in town A, from 1960 to 1962 (except during holidays), each child had been given a daily supplement of approximately $20 \mathrm{~g}$ skim milk, $7 \mathrm{~g}$ of a vegetable-protein mixture, $4^{\circ} \mathrm{g}$ banana and $10 \mathrm{~g}$ sugar.

\section{RESULTS}

Food consumption. All families regularly had three meals a day. These meals always included sugar-sweetened coffee and maize tortillas. The pattern of the diet and amounts of food consumed in each survey were almost uniform; minor changes were observed only in a few items, as seen in Table 2. In addition to maize, which is the staple food, beans were consumed daily in appreciable amounts.

The amounts of pulses (mainly black beans) consumed were remarkably similar for each town from year to year, except for the last year in town $C$. There were clear differences between the communities, town $\mathrm{C}$ having the lowest consumption, $28-38 \mathrm{~g}$, and town $A$ the highest, $71-79 \mathrm{~g} /$ person daily.

A general dietary characteristic in these Indian towns is the great variety of green leaves and other fresh vegetables used. In town $\mathrm{C}$ more than twenty-five different 
kinds of vegetable were consumed, though in small quantities. There was less variety of fruits, and the kinds and amounts eaten depended on the type of production in the locality. For instance, citrus fruits are abundant in town A and scarce in the others.

Table 2. Mean daily food consumption ( $g /$ head) of Guatemalan Indian families, in terms of edible portion, in 4 consecutive years

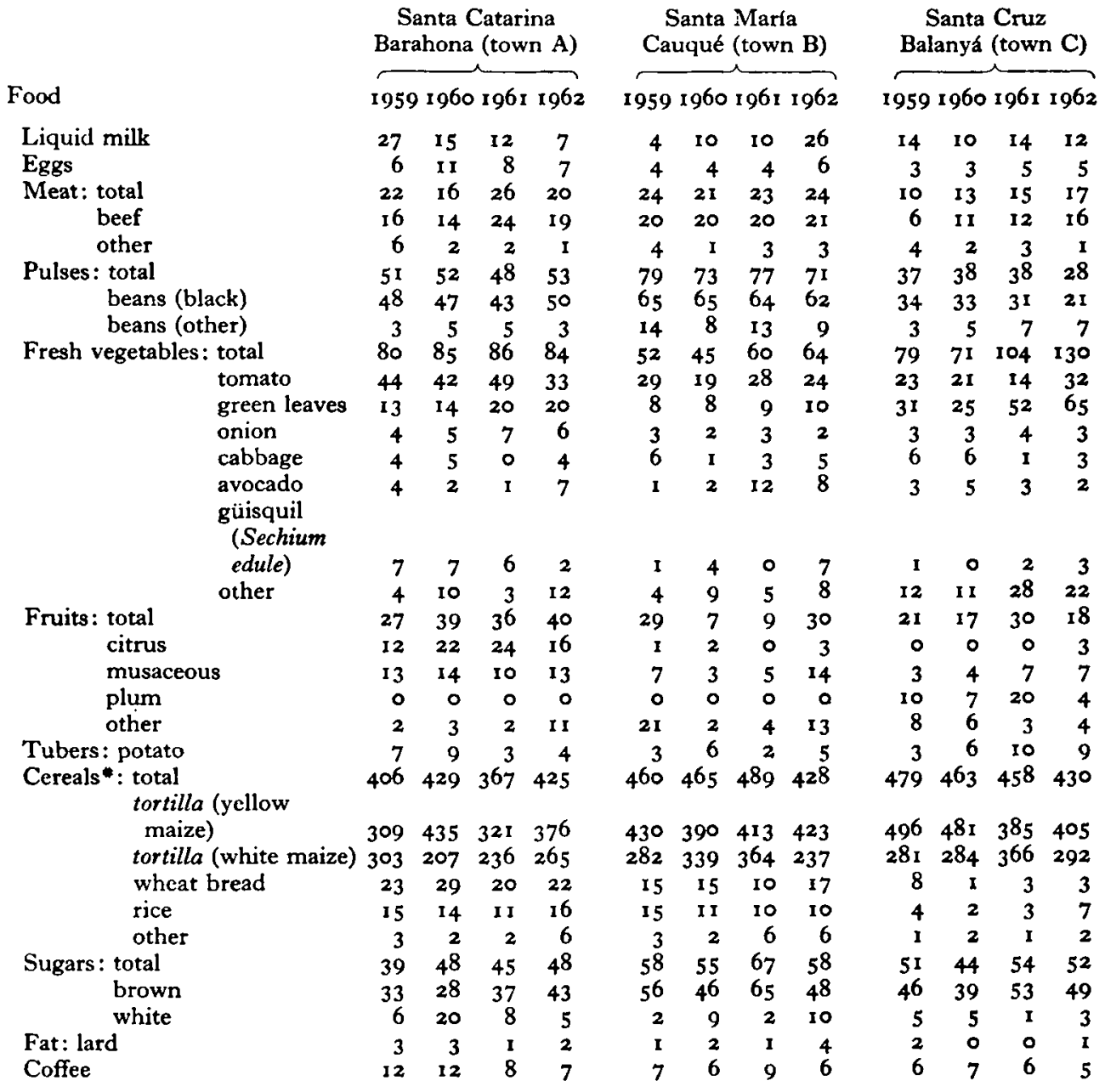

- Calculated on a dry-weight basis.

The low consumption of animal products was evident, especially in town C. In each town almost the same amounts of beef, eggs and milk were consumed on each occasion. Starchy roots were seldom consumed and fats were lacking in all diets with the exception of those of some families on Sundays, when they were used for a special maize dish called tamal.

The same food pattern is shown in the preschool children's diets (Table 3). The amounts of foods per head were smaller than those shown in Table 2, except for milk 
and fruits. It was only in town C, on the family level, that any improvement in diet appeared to be taking place over the 4 successive years. Here the figures suggested that the consumption per person of eggs, meats and vegetables was increasing. When a family with a cow happened to be included in the sample studied, some milk was given to the child, thus increasing the average figure for that product, as occurred in town $\mathrm{C}$. In town A families and children increased their fruit consumption a little over the 4 years, but annual differences were relatively very small.

\section{Table 3. Mean daily food consumption of Guatemalan Indian preschool} children ( $\mathrm{g} / \mathrm{head})$, in terms of edible portion, in 4 consecutive years

\begin{tabular}{|c|c|c|c|c|c|c|c|c|c|c|c|c|}
\hline \multirow[b]{2}{*}{ Food } & \multicolumn{4}{|c|}{$\begin{array}{c}\text { Santa Catarina } \\
\text { Barahona (town A) }\end{array}$} & \multicolumn{4}{|c|}{$\begin{array}{c}\text { Santa María } \\
\text { Cauqué (town B) }\end{array}$} & \multicolumn{4}{|c|}{$\begin{array}{c}\text { Santa Cruz } \\
\text { Balanyá (town C) }\end{array}$} \\
\hline & \multicolumn{4}{|c|}{1959196019611962} & \multicolumn{4}{|c|}{$1959 \times 960 \times 9611962$} & \multicolumn{4}{|c|}{ I959 1960 1961 1962} \\
\hline Liquid milk & 47 & I I & 8 & 36 & 5 & 27 & 28 & 40 & 13 & I 5 & 48 & 13 \\
\hline Eggs & 5 & 7 & 6 & 6 & 4 & 3 & 4 & 5 & 3 & 2 & 3 & 3 \\
\hline Meat: total & 9 & 6 & 12 & 6 & 14 & 10 & I I & 8 & 6 & 5 & 6 & 6 \\
\hline beef & 7 & 5 & Io & 6 & II & 10 & 9 & 7 & 5 & 4 & 4 & 6 \\
\hline other & 2 & I & 2 & 0 & 3 & 0 & 2 & I & I & I & 2 & 0 \\
\hline Pulses: total & Io & 14 & ro & I I & 20 & I5 & 28 & 25 & Io & 8 & 12 & I 3 \\
\hline beans (black) & 9 & I I & Io & I 1 & $\mathrm{r} 8$ & 13 & 23 & 23 & 9 & 7 & 9 & 10 \\
\hline beans (other) & $I$ & 3 & 0 & 0 & 2 & 2 & 5 & 2 & $\mathbf{I}$ & I & 3 & 3 \\
\hline Fresh vegetables: total & $4 I$ & 39 & 49 & 33 & 33 & 24 & 27 & 19 & 46 & 30 & 50 & 62 \\
\hline tomato & 22 & 22 & 27 & 12 & 17 & ro & 12 & 9 & 13 & I0 & 6 & 13 \\
\hline green leaves & 7 & 6 & 10 & 8 & 4 & 4 & 2 & 3 & 18 & 9 & 23 & 29 \\
\hline onion & 2 & 2 & 4 & 2 & 2 & I & I & I & $\mathbf{I}$ & 2 & 2 & 3 \\
\hline cabbage & $\mathrm{I}$ & I & 0 & 4 & 4 & 0 & $\mathbf{r}$ & $\mathbf{I}$ & 3 & $\mathbf{I}$ & 0 & 2 \\
\hline $\begin{array}{l}\text { avocado } \\
\text { güisquil } \\
\text { (Sechium }\end{array}$ & 3 & $\mathbf{I}$ & 2 & 2 & 2 & $\mathrm{I}$ & 9 & 0 & 3 & 4 & 2 & $\mathbf{I}$ \\
\hline edule) & 3 & 4 & 3 & $\mathbf{I}$ & I & 4 & 0 & 2 & 0 & o & I & 2 \\
\hline other & 3 & 3 & 3 & 4 & 3 & 4 & 2 & 3 & 8 & 4 & 16 & 12 \\
\hline Fruits: total & $3 \mathbf{I}$ & 34 & 38 & 40 & 17 & 17 & 8 & 31 & 20 & 19 & 44 & 31 \\
\hline citrus & 12 & 23 & 23 & 18 & I & 3 & 0 & 6 & $\mathbf{I}$ & 0 & 0 & 2 \\
\hline musaceous & 14 & 7 & 9 & 13 & 12 & 9 & 5 & 18 & 4 & 5 & 16 & 19 \\
\hline plum & 0 & 0 & 0 & 0 & 0 & 0 & 0 & 0 & 12 & 7 & 26 & 7 \\
\hline other & 5 & 4 & 6 & 9 & 4 & 5 & 3 & 7 & 3 & 7 & 2 & 3 \\
\hline Tubers: potato & 3 & 6 & 2 & 3 & 4 & 3 & I & 2 & $\mathbf{I}$ & 3 & 7 & 2 \\
\hline $\begin{aligned} \text { Cereals*: total } & \\
& \text { tortilla (yellow }\end{aligned}$ & 119 & 164 & $\times 67$ & 137 & 178 & 164 & r98 & 134 & $\mathbf{7 4}$ & 165 & 173 & 165 \\
\hline maize) & 71 & 112 & 126 & 95 & 132 & 112 & 185 & Iro & 176 & 148 & I35 & 147 \\
\hline tortilla (white maize) & 64 & 87 & 102 & 70 & 112 & $12 I$ & I IO & 74 & 97 & 114 & 144 & I I I \\
\hline wheat bread & 29 & 39 & 24 & 32 & $2 I$ & 18 & 16 & I5 & 7 & 4 & 5 & 6 \\
\hline rice & 9 & 7 & 7 & 9 & 10 & 6 & 6 & 6 & 2 & 2 & I & 3 \\
\hline other & 4 & 2 & I & I & 2 & 2 & 2 & 4 & $\mathbf{I}$ & 3 & 0 & $\mathbf{I}$ \\
\hline Sugars : total & 23 & 38 & 28 & 30 & 34 & 34 & 40 & 28 & 29 & 32 & 47 & 26 \\
\hline brown & I 8 & 25 & 21 & 22 & $3 I$ & 27 & 39 & 22 & 27 & 30 & 43 & 24 \\
\hline white & 5 & 13 & 7 & 8 & 3 & 7 & I & 6 & 2 & 2 & 4 & 2 \\
\hline Fat: lard & I & I & I & I & I & I & $\circ$ & I & I & 0 & 0 & I \\
\hline Coffee & 5 & 8 & 4 & 4 & 3 & 4 & 6 & 3 & 3 & 5 & 5 & 3 \\
\hline
\end{tabular}

* Calculated on a dry-weight basis.

Nutritive value of the diets. The mean intakes of calories and nutrients are shown in Table 4 , in which results are given for the three towns for each of the 4 years. There were some differences between the towns, but variations from year to year within each 
town were negligible. As the result of the high consumption of lime-treated maize (tortilla) in the three towns, the mean intakes of calories, total protein, calcium, thiamine, and nicotinic acid were relatively high. The percentage of calories from protein was about Io and from carbohydrates about 82 . The only nutrients that showed important differences from year to year were vitamins $\mathrm{A}$ and $\mathrm{C}$. An analysis of variance of calorie intake in the three towns for each year showed no significant differences from year to year within each town.

Table 4. Mean daily intake of calories and nutrients by Guatemalan Indian families and children in 4 consecutive years

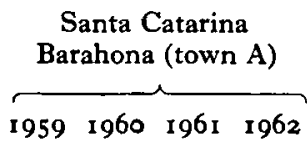

$$
\overbrace{1959 \quad 1960 \quad \begin{array}{l}
\text { Santa Maria Cauqué } \\
\text { (town B) }
\end{array}}^{\overbrace{1962}}
$$

Families (per head)

Calories (kcal)
Total protein (g)
Animal protein (g)
Fat (g)
Calcium (mg)
Iron (mg)
Vitamin A (i.u.)
Thiamine (mg)
Riboflavine (mg)
Nicotinic acid (mg)
Vitamin C (mg)

$\begin{array}{llll}1956 & 2083 & 1793 & 2054\end{array}$ $\begin{array}{lllll}56 \cdot 5 & 58 \cdot 4 & 53 \cdot 1 & 59^{\circ} \circ\end{array}$ $\begin{array}{rrrr}5.5 & 4.8 & 6.3 & 6.2\end{array}$ $\begin{array}{rrrr}19 & 20 & 16 & 20 \\ 1085 & 1137 & 1006 & 1151\end{array}$ I 202021 $26173120 \quad 3030 \quad 3867$ $\begin{array}{llll}I \cdot 1 & 1 \cdot 2 & I \cdot I & I \cdot 2\end{array}$ $\begin{array}{llll}0.6 & 0.6 & 0.6 & 0.7\end{array}$ $12.9 \quad 13.3 \quad 11.6 \quad 12.3$ $\begin{array}{llll}5 \circ & 62 & 64 & 64\end{array}$

$\begin{array}{rrrr}2234 & 2217 & 2384 & 2163 \\ 65.8 & 64.5 & 68.6 & 62.7 \\ 5.0 & 4.8 & 5.0 & 6.3 \\ 17 & 17 & 19 & 21 \\ 1216 & 1215 & 1311 & 1186 \\ 23 & 22 & 24 & 22 \\ 2223 & 1920 & 2130 & 2750 \\ 1.4 & 1.3 & 1.4 & 1 \cdot 3 \\ 0.6 & 0.6 & 0.7 & 0.6 \\ 13.1 & 12.7 & 14.2 & 12.4 \\ 32 & 25 & 33 & 51\end{array}$

Preschool children

$\begin{array}{lrrrrrrrr}\text { Calories (kcal) } & 687 & 899 & 844 & 760 & 907 & 849 & 1045 & 778 \\ \text { Total protein (g) } & 19.2 & 22.8 & 22.7 & 20.2 & 25.1 & 22.9 & 29.0 & 22.3 \\ \text { Animal protein (g) } & 3.8 & 2.4 & 3.2 & 3.2 & 3.3 & 3.2 & 3.3 & 3.5 \\ \text { Fat (g) } & 10 & 11 & 9 & 9 & 9 & 8 & 10 & 9 \\ \text { Calcium (mg) } & 352 & 397 & 434 & 374 & 445 & 442 & 561 & 414 \\ \text { Iron (mg) } & 7 & 9 & 9 & 8 & 9 & 8 & 10 & 8 \\ \text { Vitamin A (i.u.) } & 1473 & 1293 & 1427 & 1567 & 1037 & 967 & 907 & 813 \\ \text { Thiamine (mg) } & 0.4 & 0.5 & 0.5 & 0.4 & 0.5 & 0.4 & 0.6 & 0.5 \\ \text { Riboflavine (mg) } & 0.3 & 0.3 & 0.3 & 0.3 & 0.3 & 0.3 & 0.3 & 0.3 \\ \text { Nicotinic acid (mg) } & 5.1 & 6.1 & 5.4 & 4.6 & 5.5 & 5.2 & 6.4 & 4.5 \\ \text { Vitamin C (mg) } & 31 & 33 & 38 & 33 & 21 & 18 & 16 & 26\end{array}$

Santa Cruz Balanyá (town C)

$\overbrace{19591960 \quad 19611962}$

2133203520701938

$\begin{array}{lllll}57.6 & 56.4 & 58.1 & 53.5\end{array}$

$\begin{array}{lrrr}2.7 & 3.1 & 3.8 & 4.5\end{array}$

$\begin{array}{llll}17 & 14 & 14 & 14\end{array}$

$\begin{array}{lllll}1303 & 1254 & 1243 & 1183\end{array}$

$\begin{array}{llll}20 & 19 & 20 & 20\end{array}$

$\begin{array}{llll}3103 & 2493 & 2707 & 3977\end{array}$

$\begin{array}{llll}1 \cdot 2 & 1 \cdot 2 & 1 \cdot 2 & 1 \cdot 1\end{array}$

$\begin{array}{llll}0.6 & 0.6 & 0.6 & 0.6\end{array}$

II.9 I2.0 $12.2 \quad$ II.5

$\begin{array}{llll}54 & 48 & 64 & 91\end{array}$

$\begin{array}{rrrr}836 & 800 & 944 & 818 \\ 21.8 & 20.1 & 24.2 & 21.8 \\ 1.8 & 1.6 & 3.0 & 2.0 \\ 8 & 6 & 7 & 7 \\ 498 & 447 & 560 & 474 \\ 9 & 7 & 9 & 8 \\ 1597 & 920 & 1307 & 1653 \\ 0.5 & 0.4 & 0.5 & 0.4 \\ 0.3 & 0.2 & 0.4 & 0.2 \\ 4.9 & 5.0 & 5.6 & 4.9 \\ 32 & 20 & 34 & 40\end{array}$

In town $A$ there was a higher intake of animal protein, particularly in I96I and I962 when it constituted II-I $2 \%$ of the total protein; in the other two towns it reached only 5 and $7 \%$. In town $B$, where the people had the most monotonous diet, they had the highest intake of calories and the lowest of vitamins $A$ and $C$. In town $C$, where the families included in their diets more vegetables in the 4 th year (1962), the intake of vitamins $A$ and $C$ improved, especially that of vitamin $C$, in both family and children's diets.

The mean intakes per child showed very slight differences, not only from year to year, but between towns as well, except in vitamins $A$ and $C$. When direct estimates for children are compared with per head consumption levels on a family basis, it 
becomes evident that the intake per child was limited in all nutrients, amounting only to about $50 \%$ of the calculated mean intake for an individual within the family. Children would be expected to have lower intakes than the mean for the family, but $50 \%$ of the consumption seems to be extremely low, even if the intakes were more or less adequate per individual at family level. Most of the children whose diets were studied were weighed when the families were being interviewed for the dietary surveys, and the mean weights are presented in Table 5 . Heights wcre not taken, but it was established by Scrimshaw \& Guzmán (1953) that children in these villages, when they reach school age, are approximately $2-4$ years behind USA children in weight and height.

Table 5. Mean weights of children including the three communities in 4 years

$\begin{array}{cccc}\text { Age (years) } & \text { No. of children } & \text { Weight }(\mathrm{kg}) & \text { SD } \\ <\text { I } & 6 & 7 \cdot 7 & 1 \cdot 8 \\ 1 & 41 & 8 \cdot 8 & 1 \cdot 3 \\ 2 & 68 & 9 \cdot 9 & 1 \cdot 3 \\ 3 & 91 & 11 \cdot 2 & 1 \cdot 8 \\ 4 & 57 & 12 \cdot 5 & 2 \cdot 4 \\ 5 & 13 & 13 \cdot 8 & 1 \cdot 5\end{array}$

Adequacy of the diets. The adequacy of intakes of calories and nutrients was estimated by comparing the findings with the recommended allowances per individual and per child. Only the results for the Ist year are shown in Fig. I, because of the striking consistency of results during the 4 years.

All intakes, calculated per head in each family, reached the recommended allowances for all nutrients except vitamins $\mathrm{A}$ and $\mathrm{C}$ and riboflavine. Vitamin $\mathrm{C}$ intake reached more than $80 \%$ of the allowance in towns $\mathrm{A}$ and $\mathrm{C}$, but reached only about $50 \%$ in town B. However, vitamin C intakes rose in the last 2 years in all of the towns. The children's intakes were consistently lower than the recommended allowances for all nutrients except iron. Riboflavine and calcium intakes reached only $30-40 \%$ and $40-50 \%$ of the allowances, respectively.

To ascertain if there was a relationship between consumption of animal protein by the family and by the preschool child, values for the 4 years were used for both families and children. The three communities were taken as a whole and families were divided into five groups as regards the average amount of animal protein consumed per day (some families did not have any animal protein in their diets, and they were not included):

$\begin{array}{cc}\text { Group } & \text { Daily intake of animal protein } \\ 1 & (\mathrm{~g}) \\ 1 & 0-3 \\ 2 & 3.01-6 \\ 3 & 6 \cdot 01-9 \\ 4 & 9.1-12 \\ 5 & 12 \cdot 01 \text { and more }\end{array}$

The animal protein intakes of families and children were averaged for each group and the results are presented in Fig. 2. The mean intake of the children increased with increasing consumption by the family, but not in exact proportion. 

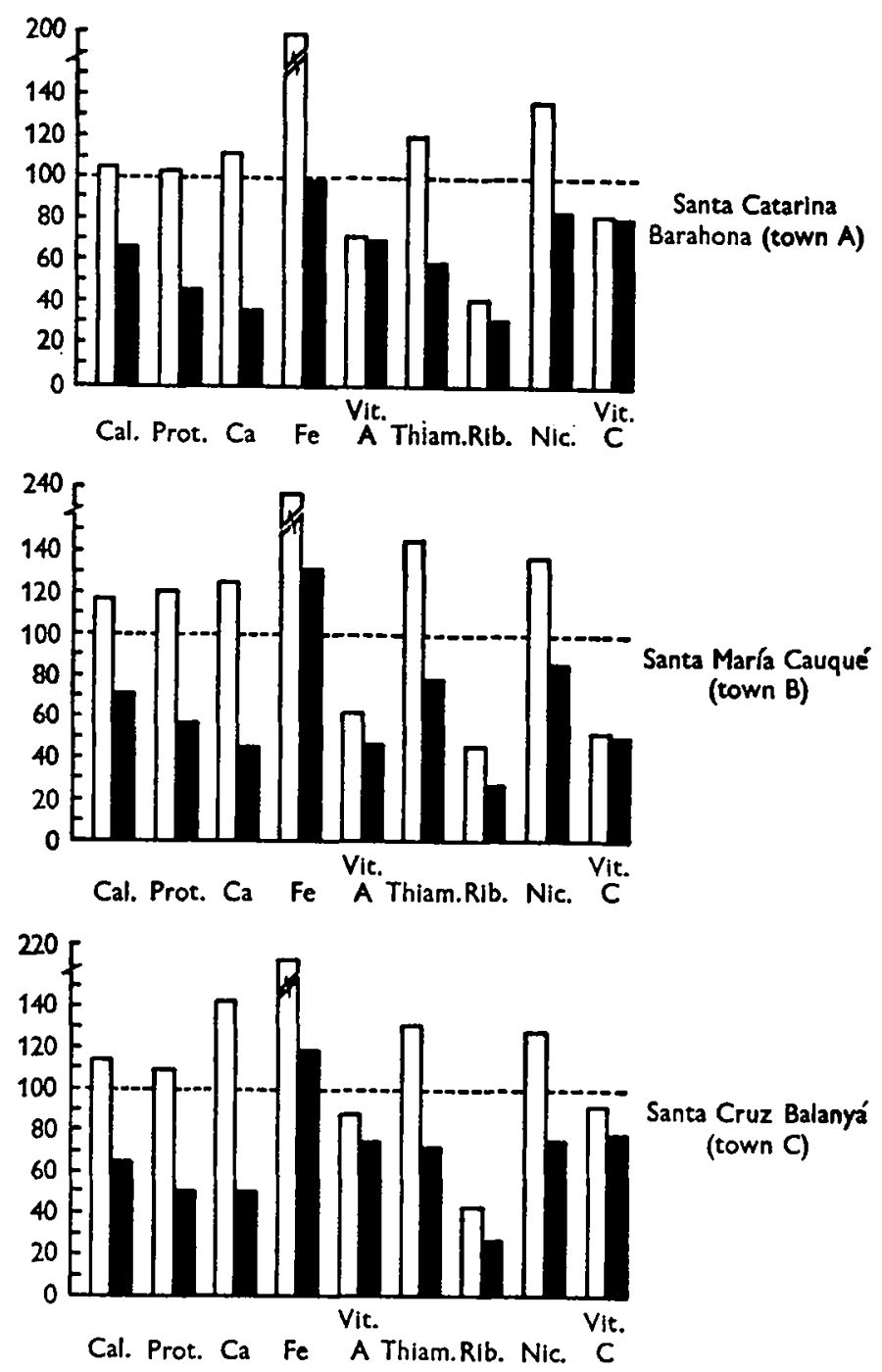

Fig. I. Adequacy of intake of nutrients/head, expressed as a percentage of the recommended allowances (Instituto de Nutrición de Centro América y Panamá, 1953a), by families and preschool children in three Guatemalan Indian communities, 1959. $\square$, family; $\bullet$, child

Sources of calories and nutrients. The main constituents of the family and children's diets were similar, but some foods were used mainly by children, others by adults. Consequently, the contribution of various foods to the total intake of nutrients shows some differences between children and families. Table 6 presents the proportions of calories and nutrients derived from food groups for town B in 1962. Results for previous years were very similar for both towns $B$ and $C$. In town $A$ the values for calcium and riboflavine changed when the feeding programme for preschool children was established, because milk and other supplements were given to them. Cereals accounted for a lower proportion of the total calories in the diets of children than of families, the deficit being made up by dairy produce and sugar. Dairy produce 
accounted for a relatively greater proportion of the protein, calcium and riboflavine in the diets of the children.

Vegetables contributed $69 \%$ of the vitamin $\mathrm{C}$ in the family diets, whereas in the children's diets it was $46 \%$. The children derived $3 \mathrm{I}$ and $12 \%$ of their vitamin $\mathrm{C}$ from fruits and bananas respectively.

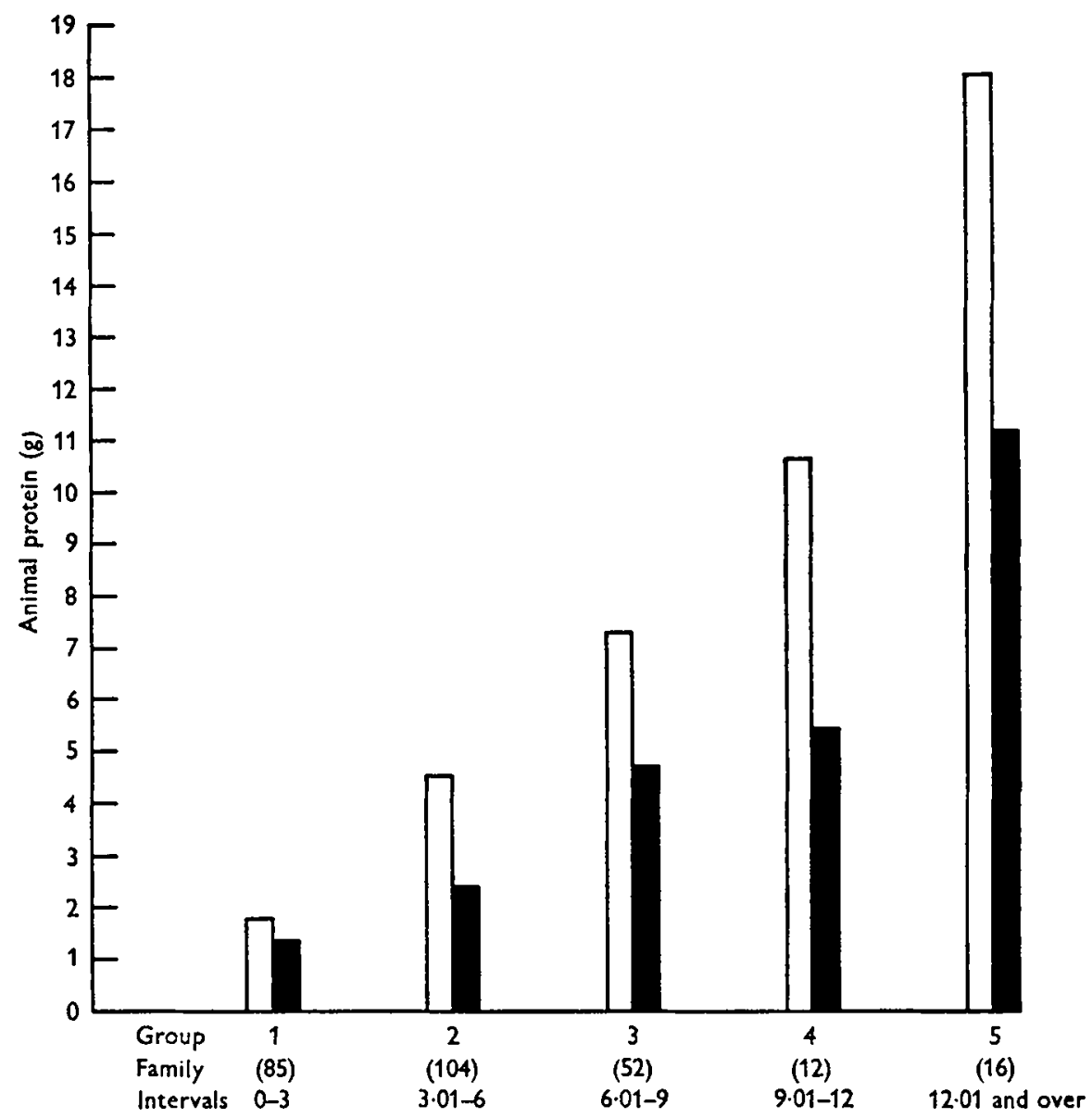

Fig. 2. Animal protein intake/head of families and preschool children in three Guatemalan Indian communities, 1959-62. $\square$, family; $₫$, child.

\section{DISCUSSION}

In some previous individual dietary studies of preschool children the weighing method was used (Flores \& García, 1960). For this purpose the nutritionist has to spend several hours each day with the mother in order to measure the child's food consumption, which results in a great interference in the family life which causes the mother to alter her normal routine. For this reason, in the study now reported, a recall method using household measures was adopted to obtain information about both families and children. Small children do not follow a regular eating schedule, however, 
and the consumption of certain foods between meals becomes very important. The estimation of the intake of children depends mostly on the information obtained from the mother, and foods between meals are not always remembered. The values presented here may therefore underestimate the true intake, at least so far as the children are concerned.

Table 6. Percentage contribution of food groups to dietary nutrients of families with preschool children in Santa Maria Cauque in 1962

\begin{tabular}{|c|c|c|c|c|c|c|c|c|c|}
\hline Food group & Calories & $\begin{array}{l}\text { Pro- } \\
\text { tein }\end{array}$ & $\begin{array}{l}\text { Cal- } \\
\text { cium }\end{array}$ & Iron & $\begin{array}{l}\text { Vita- } \\
\text { min A }\end{array}$ & $\begin{array}{l}\text { Thia- } \\
\text { mine }\end{array}$ & $\begin{array}{l}\text { Ribo- } \\
\text { flavine }\end{array}$ & $\begin{array}{l}\text { Nico- } \\
\text { tinic } \\
\text { acid }\end{array}$ & $\begin{array}{l}\text { Vita- } \\
\text { min C }\end{array}$ \\
\hline \multicolumn{10}{|c|}{ Families (20) } \\
\hline Milk and milk products & 0.9 & $1 \cdot 3$ & 3.9 & 0.5 & $2 \cdot \mathbf{I}$ & 0.8 & 9.7 & 0.1 & 0.0 \\
\hline Eggs & 0.5 & $1 \cdot 1$ & 0.3 & 0.9 & $2 \cdot 5$ & 0.8 & $3 \cdot 2$ & 0.0 & 0.0 \\
\hline Meat & $I \cdot 4$ & $7 \cdot 4$ & $0 \cdot 2$ & $15 \cdot 2$ & $0 \cdot 2$ & $1 \cdot 6$ & $6 \cdot 5$ & 10.4 & 0.0 \\
\hline Pulses & $11 \cdot 6$ & 23.5 & 8.4 & $20 \cdot 3$ & 0.4 & $26 \cdot 4$ & $16 \cdot 1$ & $I x \cdot 0$ & $3 \cdot 9$ \\
\hline Fresh vegetables & $1 \cdot 4$ & $2 \cdot 1$ & $3 \cdot 1$ & $7 \cdot 4$ & 40.0 & 4.7 & $9 \cdot 7$ & 4.5 & $68 \cdot 6$ \\
\hline Fruits other than musaceous & 0.4 & 0.1 & 0.3 & 0.0 & $4 \cdot 6$ & 0.0 & 0.0 & 0.5 & $19 \cdot 6$ \\
\hline Musaceous fruits & 0.7 & 0.2 & 0.1 & 0.0 & $13 \cdot 9$ & 0.0 & 0.0 & 0.7 & $3 \cdot 9$ \\
\hline Starchy roots & 0.2 & 0.2 & 0.0 & $0 \cdot 0$ & 0.0 & 0.0 & $0 \cdot 0$ & 0.6 & $2 \cdot 0$ \\
\hline Cereals & $70 \cdot 2$ & $62 \cdot 0$ & $80 \cdot 8$ & $46 \cdot 1$ & $34 \cdot 5$ & $65 \cdot 1$ & $48 \cdot 4$ & $5^{8 \cdot 2}$ & 0.0 \\
\hline Sugar & $9 \cdot 7$ & 0.4 & $2 \cdot 5$ & $7 \cdot 8$ & 0.2 & 0.8 & 6.5 & $1 \cdot 0$ & $2 \cdot 0$ \\
\hline Fat & $I \cdot 5$ & 0.0 & 0.0 & 0.0 & $1 \cdot 3$ & 0.0 & 0.0 & 0.0 & 0.0 \\
\hline Miscellaneous & $1 \cdot 5$ & $I \cdot 6$ & 0.5 & $I \cdot 8$ & 0.1 & 0.0 & 0.0 & $12 \cdot 9$ & 0.0 \\
\hline \multicolumn{10}{|c|}{ Preschool children (20) } \\
\hline Milk and milk products & $3 \cdot 3$ & $5 \cdot 9$ & 17.4 & $2 \cdot 5$ & $8 \cdot 6$ & $4 \cdot 3$ & $30 \cdot 0$ & 0.4 & $3 \cdot 8$ \\
\hline Eggs & $1 \cdot 0$ & $2 \cdot 5$ & 0.7 & $2 \cdot 5$ & $7 \cdot 0$ & $\mathbf{2} \cdot \mathbf{1}$ & $6 \cdot 7$ & 0.0 & 0.0 \\
\hline Meat & $x \cdot 3$ & 6.9 & 0.2 & I 3.9 & 0.0 & $2 \cdot 1$ & $3 \cdot 3$ & $9 \cdot 6$ & \\
\hline Pulses & $11 \cdot 7$ & $24 \cdot 6$ & $8 \cdot 9$ & $20 \cdot 3$ & 0.4 & $3 I \cdot 9$ & $13 \cdot 3$ & I3. I & 3. \\
\hline Fresh vegetables & $1 \cdot 0$ & $1 \cdot 8$ & $2 \cdot 7$ & 6.3 & $40 \cdot 6$ & $4 \cdot 3$ & 6.7 & $3 \cdot 6$ & 46 \\
\hline Fruits other than musaceous & 0.9 & 0.3 & 0.7 & $1 \cdot 3$ & $8 \cdot 6$ & 0.0 & 0.0 & 0.9 & 30.8 \\
\hline Musaceous fruits & $2 \cdot 4$ & 0.9 & 0.2 & $I \cdot 3$ & $4 \cdot 1$ & 0.0 & $3 \cdot 3$ & $2 \cdot 9$ & II. 5 \\
\hline hy roots & 0.3 & 0.2 & 0.0 & 0.0 & 0.0 & 0.0 & 0.0 & 0.7 & $3 \cdot 8$ \\
\hline Cereals & $6 I \cdot 7$ & $54^{\circ} 0$ & 65.0 & $39 \cdot 2$ & $30 \cdot 3$ & $53 \cdot 2$ & $30 \cdot 0$ & $49 \cdot 3$ & 0.0 \\
\hline Suga & $13 \cdot 1$ & 0.5 & 3.4 & IO. I & 0.4 & $2 \cdot I$ & 6.7 & $I \cdot 3$ & 0 \\
\hline Fat & $1 \cdot 2$ & 0.0 & 0.0 & 0.0 & - & 0.0 & 0.0 & 0.0 & 0.0 \\
\hline Miscellaneous & $2 \cdot 1$ & $2 \cdot 3$ & 0.7 & $2 \cdot 5$ & 0.0 & 0.0 & 0.0 & $18 \cdot 2$ & \\
\hline
\end{tabular}

As mentioned already, a random sample was drawn every year from each village, and some families included in the sample of the Ist year were, by chance, selected again in the following years. The Indian families were found to be more co-operative when they had already been investigated. After the first experience they understood more easily the nature of the study and knew how to give the information that was required. This may have introduced a bias in those particular families on the second occasion, but, on the other hand, it is usually accepted that food habits are resistant to change ((USA) National Research Council, 1943).

Often availability of foods and other socio-economic factors may influence the pattern of food consumption, and in these towns dietary changes due to the considerable physical and socio-economic alterations might have been expected. The surveys took place each year during the same months, so seasonal factors did not influence the results. It was found that the amounts of food consumed in each town were very 
similar from year to year. Furthermore, the results of this study in one of the towns, when compared with those of surveys carried out in the same town ro years before, showed amazingly small variation.

If the published figures for dietary requirements are applicable to these Indian communities, mean nutrient intakes per child, compared with mean intakes over the whole family, are very low, which suggests that some members of the family are getting more than their share, and are, therefore, limiting the consumption of the small children. When sources of nutrients by food groups were calculated per child and per family, it was found that expensive foods like milk, eggs and fruit tended to be given to children in preference to adults but, in spite of it, when the nutritive value of diets was compared with estimated requirements, the small children were found to be getting a smaller percentage of their requirement of calories and of every dietary constituent included in the calculations, and this was true in each of the three towns.

The relationship between the animal protein intake of the family and that of the individual child has been discussed by Leitch \& Aitken (1949-50), who stated that 'if total supply of the family is inadequate the whole family will suffer in greater or less degree'. It was observed, however, that if the family as a whole took more animal protein the preschool child did not benefit to the same extent. If families with a greater supply of animal food would learn the needs of the small child for this type of food, the child would be in a better state of nutrition. The only animal protein sources considered suitable for small children in this population are milk and eggs. Meat and meat products are not offered to the small children except in very limited amounts, even when these foods are available to the family. The deficient diet of the preschool child is due not only to the shortage of good-quality food but also to prejudice and lack of knowledge about the feeding of small children.

\section{SUMMARY}

I. Dietary surveys lasting 3 days were repeated yearly in three Indian towns over a period of 4 years, 1959 through 1962 . During April, May and June of each year, a sample of twenty or thirty families and twenty or thirty individual children from I to 5 years of age in these families were investigated in each town.

2. An outstanding feature of the findings was the constancy in food consumption from family to family and from child to child over the 4 successive years. Changes were expected, since two of the towns had been exposed to outside influences that have affected other living patterns of the people. Differences between the towns depended on the availability of types of food in each locality.

3. The food pattern of the preschool children was the same as that of their families, but amounts of foods consumed by the individual children were less than the mean per head consumption in the family. When nutrient intakes were compared with INCAP recommended allowances, it was seen that the family diets were adequate in most of the nutrients, but provided less than the recommended amounts of vitamin $A$ and riboflavine, and in two towns also of vitamin $\mathrm{C}$. The mean intakes per child, however, were below recommended allowances for all the nutrients except iron. The most 
severe dietary deficiencies appeared to be of vitamin A, riboflavine and calcium, although calories and protein were limited as well.

4. The problem of food distribution within the families is discussed.

\section{REFERENCES}

Bressani, R., Paz y Paz, R. \& Scrimshaw, N. S. (1958). Y. agric. Fd Chem. 6, 770.

Flores, M., Flores, Z. \& Meneses, B. (1957). Arch. venez. Nutr. 8, 57.

Flores, M. \& Garcfa, B. (1960). Brit. J. Nutr. 14, 207.

Flores, M. \& Reh, E. (1955). Bol. ofic. Sanit. pan-amer. Suppl. no. 2, p. 163.

Instituto de Nutrición de Centro América y Panamá (1953a). Bol. ofic. Sanit. pan-amer. Suppl. no. I, p. I 19 .

Instituto de Nutrición de Centro América y Panamá (1953b). Bol. ofic. Sanit. pan-amer. Suppl. no. I, p. 129.

Leitch, I. \& Aitken, F. C. (1949-50). Nutr. Abstr. Rev. 19, 507.

National Research Council (1943). Bull. nat. Res. Coun., Wash., no. 108.

Scrimshaw, N. S. \& Guzmán, M. A. (1953). In Current Research on Vitamins in Trophology, p. 10r. New York: National Vitamin Foundation, Inc. 